\title{
STANDARDISASI PEKERJAAN PEMELIHARAAN PERTAMANAN DI KABUPATEN JEMBER
}

\section{Standardization of Park \\ Maintenance Works in Jember Regency}

\author{
Rindha Rentina Darah Pertami \\ Jurusan Produksi Pertanian, \\ Politeknik Negeri Jember \\ Email: rindha_rentina@polije.ac.id
}

\section{Jumiatun}

Jurusan Produksi Pertanian, Politeknik Negeri Jember

Email: Jumiatun@polije.ac.id

\section{Bety Etikasari}

Jurusan Teknologi Informasi,

Politeknik Negeri Jember

Email: bety.etikasari@gmail.com

\begin{abstract}
The initial step to improve the quality of green open space requires robust studies related to the activities to be carried out which development results are obtained from in-depth and intact analysis. Therefor, the work results are in line with expectations and uniform, it is necessary to have a standard in works implementation. The purpose of this study is to identify the classification and criteria for urban parks, to calculate the capacity of daily workers for park maintenance, and to determine the intensity of maintenance works in different seasons. The classification and criteria for urban parks are in accordance with the regulation standard of Minister of Public Works which dividing the criteria for parks into neighborhood parks and community parks having green area of $70-80 \%$ of total areas. Urban village parks, district parks, and city parks must have green area of at least $80-90 \%$ of the park area. The amount of work capacity depends on the level of work difficulty as well as the skills and capabilities of the workers. Determining the intensity of maintenance work in the park, besides having to consider various factors such as the total area of the components in the park (hardscapes and softscapes of the park), the work capacity of each maintenance activities, the frequency of maintenance work in the rainy and dry seasons, and the time of day effective of workforce.
\end{abstract}

Keywords: infrastructure standards, park standard, work standards

Diterima: 12 Juli 2021

\section{PENDAHULUAN}

Standardisasi pekerjaan pemeliharaan pertamanan bertujuan untuk menjamin stabilitas (konsistensi), acuan untuk mengukur performance, evaluasi dan perbaikan (continuous improvement), meningkatkan efisiensi, produktivitas kinerja serta mengoptimalkan fungsi rantai pelayanan di perusahaan (dari internal hingga eksternal). Ruang terbuka yang seharusnya dapat diakses oleh siapapun, seiring dengan kebutuhan lahan yang meningkat dewasa ini banyak yang dikelilingi oleh bangunan menjadikan keterbukaan tersebut menjadi terbatas dan hanya orang yang memiliki tujuan khusus yang akan menggunakan ruang terbuka tersebut (Hantono, 2017; Permata et. al., 2019; Setyabudi dan Agus, 2020). Karakteristik taman yang teduh, adanya rumput, dan fasilitas permainan anak, menjadi elemen yang menarik kegiatan warga di taman (Noor et al., 2018). Meningkatnya kualitas ruang terbuka hijau yang menyeluruh terkait dengan kegiatan-kegiatan yang akan dilaksanakan sehingga diperoleh hasil perencanaan yang berasal dari analisis yang mendalam dan utuh. Namun, di lain sisi agar hasil pekerjaan sesuai dengan harapan dan seragam, maka diperlukan standar tentang pelaksanaan suatu pekerjaan.

Penyusunan panduan pemeliharaan pertamanan yang dapat dijadikan sebagai salah satu acuan/referensi dalam merancang dan menentukan jenis, desain, rencana penganggaran taman serta tenaga pemeliharaan sehingga didapatkan hasil perencanaan yang komprehensif dengan sarana prasarana yang terstandardisasi dan berkualitas. Tidak terjaminnya tersedianya taman yang terpelihara dengan baik serta memenuhi standar kelayakan yang diakui oleh internasional bahwa taman adalah tempat rekreasi, bermain dan olah raga masyarakat, area yang menjadi daya tarik dan landmark kota, area konservasi air tanah, area pengembangan keanekaragaman hayati dan area penciptaan iklim mikro dan pereduksi polutan. Tujuan dari penelitian ini adalah teridentifikasinya klasifikasi dan kriteria taman perkotaan berdasarkan Permen PU Nomor 05/PRT/M/2008, menghitung Kapasi-tas Pekerja Harian Lepas (PHL) dalam pemeliharaan taman berdasarkan data responden, dan menentukan intensitas pekerjaan pemeliharaan pada musim yang berbeda dan kebutuhan pekerja pada taman.

\section{METODE PENELITIAN}

Penelitian dilaksanakan pada bulan April sampai dengan Oktober 2020 di Kabupaten Jember. Kajian standardisasi ini menggunakan pendekatan benchmarking dengan data sekunder yang diperoleh melalui pengisian kuesioner oleh responden, dan studi pustaka dari berbagai literatur terkait standardisasi pekerjaan pemeliharaan yang ada pada Dinas Pertamanan Kabupaten Jember dan standar desain berdasarkan Permen PU Nomor 05/PRT/M/2008. Penentuan responden untuk penetapan standardisasi pekerjaan pemeliharaan didasarkan pada kredibilitas profesionalisme yang sudah diberikan oleh perusahaan atau organisasi responden di bidang pemeliharaan lanskap dalam kurun waktu tertentu dan terbukti telah berhasil mengorganisasi pekerjaan pemeliharaan dengan baik.

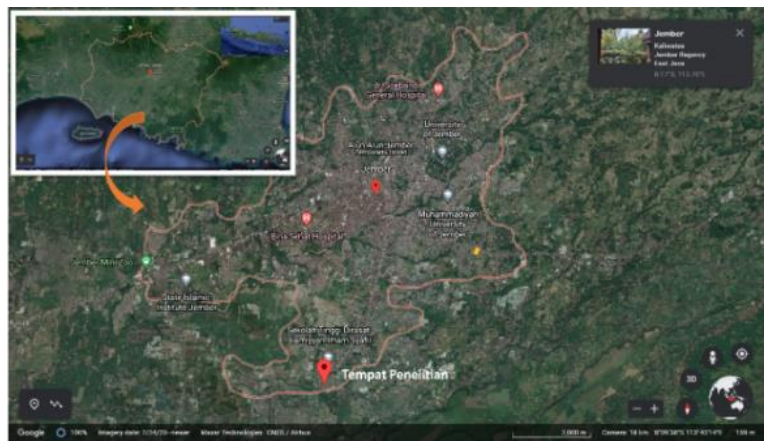

Gambar 1. Peta Citra Kabupaten Jember Sumber: Google Earth 


\section{Pengumpulan Data}

Pengumpulan data terkait kapasitas kerja pemeliharaan lanskap dilakukan dengan metode kuesioner yang disebarkan kepada responden yang terbukti mewakili perusahaan atau organisasi yang telah melakukan pekerjaan di bidang pemeliharaan lanskap dan desain lankap pada kurun waktu tertentu dan memiliki kredibilitas.

Untuk mengetahui berapa tenaga yang dibutuhkan dalam menangani satuan luasan taman diperlukan informasi terkait standar pemeliharaan yang hendak dicapai (misalnya frekuensi), waktu pelaksanaan, luasan area atau panjang dari luasan pekerjaan yang terlibat, dan waktu rata-rata per unit area yang dibutuhkan untuk menyelesaikan tugas tertentu.

Kapasitas kerja untuk setiap jenis pekerjaan pemeliharaan mengikuti standar tertentu sesuai situasi dan kondisi wilayah taman yang akan dipelihara. Dalam studi ini, penentuan standar kapasitas kerja untuk setiap jenis pekerjaan pemeliharaan dilakukan dengan mengumpulkan data dari responden tentang standar kapasitas kerja yang diberlakukan di beberapa instansi/perusahaan. Setiap responden diminta untuk mengisi Tabel 1 yang merupakan penilaian tentang kapasitas kerja yang biasa dilakukan di lingkungan kerja masing-masing responden.

Tabel 1. Tabel Penilaian Kapasitas Kerja untuk diisi Responden

\section{Pekerjaan Pemeliharaan Taman}

Pemeliharaan Rubberfloor

Pencucian Pedestrian (Paving Blok, Concrete, Keramik

Tekstur Difabel)

Pembersihan Sampah di Kolam/Danau

Pengerukan Sedimen Kolam Alami (Manual)

Pembersihan/Penyapuan Areal Rumput

Pembersihan/Penyapuan Areal Perkerasan

Penyiraman Rumput dan Tanaman Penutup Tanah dengan Sprinkler

Penyiraman Rumput dan Tanaman Penutup Tanah dengan Selang Plastik 3/4 inch

Penyiraman Pohon dengan Selang Plastik 3/4 inch

Pemangkasan Rumput dengan Mesin Dorong Rover

Pemangkasan Rumput dengan Mesin Gendong

Pemangkasan Tanaman Semak dan Tanaman Penutup

Tanah dengan Gunting Pangkas

Pemangkasan Bentuk Tanaman Perdu dan Pohon Kecil dengan Gunting Pangkas

Penyiangan dan Penggemburan Pohon dengan Cangkul dan Kored

Penyiangan Dan Penggemburan Tanaman Semak dengan Cangkul Dan Kored

Pemupukan Pupuk Organik pada Tanaman Penutup Tanah

Pemupukan Pupuk Anorganik pada Tanaman Penutup

Tanah

Pemupukan Pupuk Organik pada Pohon

Pemupukan Pupuk Anorganik pada Pohon

Penyemprotan Pestisida pada Tanaman Penutup Tanah dan Semak dengan Sprayer Gendong

Penyemprotan Pestisida pada Pohon Kecil dan Semak dengan Sprayer Gendong

Penyulaman Tanaman Rumput (Tandur)
Pekerjaan Pemeliharaan Taman

Penyulaman Tanaman Rumput (Lempengan)

Penyulaman Tanaman Penutup Tanah dan Semak

Penyulaman Tanaman Pohon

Penyikatan Perkerasan/Keramik

Pembuangan Sampah Taman Sejauh sd. $200 \mathrm{~m}$

Pembuangan Sampah Taman Sejauh 201 - 500 m

Pengerukan Sedimen Saluran Drainase

Pembersihan Lantai Bangunan Taman

Pemasangan Steiger Pohon

Pemangkasan Pohon Sedang

Pemangkasan Pohon Ringan

Kapasitas Pemeliharaan Pagar Sling

Pengetrikan Rumput

Pekerjaan Pemangkasan Ringan/Pohon Kecil (Diam Tajuk

$<5$ m Tinggi 3-6 m) Termasuk Angkutan Keluar Taman

Pekerjaan Pemangkasan Pohon Besar dengan Tinggi

$>6 \mathrm{M}$ (PP Termasuk Angkutan)

Kapasitas Kerja Pemangkasan Berat

Pekerjaan Pemangkasan Sedang $(\varnothing<5 \mathrm{~m})$

Pekerjaan Pemangkasan Berat $(\varnothing<5 \mathrm{~m})$

Pekerjaan Pemangkasan Ringan (Ø 5,1-10 m)

Pekerjaan Pemangkasan Sedang ( $\varnothing$ 5,1-10 m)

Pekerjaan Pemangkasan Berat ( $\varnothing$ 5,1-10 m)

Pekerjaan Pemangkasan Ringan $(\varnothing>10 \mathrm{~m})$

Pekerjaan Pemangkasan Sedang $(\varnothing>10 \mathrm{~m})$

Pekerjaan Pemangkasan Berat $(\varnothing>10 \mathrm{~m})$

Keterangan: $\varnothing$ adalah diameter tajuk

\section{Analisis Data}

Data yang telah dikumpulkan, terlebih dahulu dilakukan uji validitas untuk melihat valid tidaknya data yang diperoleh. Hal ini perlu dilakukan untuk mengurangi bias data akibat perbedaan yang terlalu menonjol antara data dari satu responden dengan responden lainnya.

Setelah melalui uji validitas data, maka data responden terkait kapasitas kerja ini diolah sedemikian rupa dan diambil rata-rata untuk kemudian dijadikan standar kapasitas kerja yang nantinya akan menjadi dasar perhitungan dalam jumlah Pekerja Harian Lapang (PHL) yang dibutuhkan untuk merawat dan memelihara taman pada suatu luasan tertentu. Untuk standar desain, beberapa hasil studi literatur disusun dan dibandingkan dengan kondisi setempat apakah sesuai atau tidak. Selanjutnya dibuat gambar ulang standar desain yang tepat dan sesuai.

Jam kerja produktif per minggu atau per bulan juga seringkali bervariasi sesuai organisasi dan motivasi tim, didasarkan pada jam kerja normal per minggu yaitu 40 jam kerja sebagaimana ditetapkan dalam UndangUndang No. 13 Tahun 2003 Pasal 77 ayat 1 dimana ketentuan jam kerja diatur dalam 2 sistem yaitu jam kerja dalam 1 hari atau 40 jam kerja dalam 1 minggu untuk 6 hari kerja dalam 1 minggu atau jam kerja dalam 1 hari atau 40 jam kerja dalam 1 minggu untuk 5 hari kerja dalam 1 minggu

Perhitungan 40 jam kerja ini adalah waktu ideal bekerja tanpa mempertimbangkan kemungkinan pekerja sakit, cuti, ijin, dan lain-lain. Menurut UU No. 13 Tahun 2003 disebutkan bahwa jam kerja yang normal adalah 40 jam kerja dalam 1 minggu. Rumus umum yang dapat digunakan untuk menghitung jumlah staf yang 
dibutuhkan dengan waktu produktif dan performa yang kurang (banyak ijin atau sakit) adalah sebagai berikut:

$$
\frac{120 \text { (waktu standar per minggu) }}{30 \text { (waktu produktif per minggu) }} \times \frac{100}{80 \text { performa }}=5 \text { staft }
$$

Dibandingkan dengan staf yang berada dalam kondisi prima dengan perhitungan contoh sebagai berikut:

Formula (2)

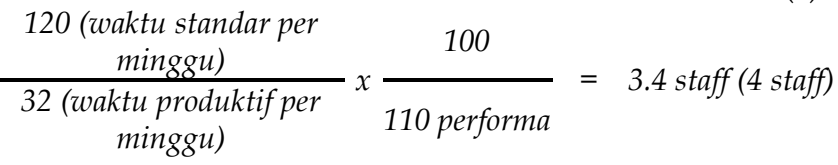

Kedua perbandingan di atas, untuk sebuah luasan yang sama, jumlah staf pekerja yang dibutuhkan dapat berbeda tergantung pada performa dan kegesitan pekerja. Pekerja yang lamban (performa kurang) dan sering ijin atau bolos (waktu tidak produktif) akan membutuhkan lebih banyak orang dalam tim nya untuk mencapat hasil yang sama dibandingkan tim yang diisi oleh orang-orang pekerja yang gesit (performa sangat baik) dan produktif (jarang bolos atau sakit). Perhitungan performa atau kinerja dapat dilakukan dengan melakukan pengamatan terhadap pekerjaan yang dilakukan individu atau kelompok kecil yang diukur di tiap akhir minggu dengan standar waktu tertentu (bisasanya jam), lalu dibagi dengan waktu yang diberikan untuk bekerja.

Formula (3)

Performa $=\underline{\text { work completed (standard hours) }} \times 100 \%$ Attendance hours

Penelitian ini diawali dengan penghitungan kapasitas kerja untuk masing-masing pekerjaan pemeliharaan yang kemudian akan dijadikan dasar dalam perhitungan HOK untuk menghitung jumlah tenaga kerja yang dibutuhkan dalam mengerjakan satu luasan taman. Kapasitas kerja memiliki satuan $\mathrm{m}^{2}$ /OrangJam (meter per segi per orang jam) sesuai dengan rumus yang tertera pada Formula 1 di atas. Untuk menghitung ke dalam HOK, maka kapasitas kerja harus dikonversi ke dalam 1 hari ( 1 hari adalah 7

\begin{tabular}{|c|c|c|}
\hline Pekerjaan Pemeliharaan Taman & $\begin{array}{l}\text { Kapasitas } \\
\text { Kerja Per } \\
\text { Hari }\left(\mathrm{m}^{2}\right)\end{array}$ & $\begin{array}{c}\text { Jumlah } \\
\text { Tenaga/M } \\
\text { 2/Hari } \\
\text { (HOK) }\end{array}$ \\
\hline Pemeliharaan Rubberfloor & 2247,0 & 0,0004 \\
\hline $\begin{array}{l}\text { Pencucian Pedestrian (Paving Blok, } \\
\text { Concrete, Keramik Tekstur Difabel) }\end{array}$ & 2247,0 & 0,0004 \\
\hline $\begin{array}{l}\text { Pembersihan Sampah di } \\
\text { Kolam/Danau }\end{array}$ & 595,0 & 0,0017 \\
\hline Pengerukan Sedimen Kolam Alami & 67,2 & 0,0149 \\
\hline
\end{tabular}
jam sesuai dengan UU No. 13 tahun 2003) sehingga

\begin{tabular}{|c|c|}
\hline Pekerjaan Pemeliharaan Taman & $\begin{array}{lc}\text { Kapasitas } & \text { Jumlah } \\
\text { Kerja Per } & \text { Tenaga/M } \\
\text { Hari }\left(\mathrm{m}^{2}\right) & \text { (HOKi } \\
\text { (HOK) }\end{array}$ \\
\hline
\end{tabular}
satuan untuk HOK adalah $\mathrm{OH}$ (orang hari). Sedangkan rumus untuk menentukan HOK adalah Formula 4.

$\frac{\text { Luasan }\left(\mathrm{m}^{2}\right)}{\begin{array}{l}\text { Kapasitas Kerja } \\ \left(\mathrm{m}^{2} / \text { OrangJam }\right)\end{array}} \times \frac{\begin{array}{c}1 \\ \text { hari }\end{array}}{7 \text { jam }}=\begin{gathered}\text { Orang Hari } \\ (\mathrm{HOK})\end{gathered}$

(Manual)

Pembersihan/Penyapuan Areal 2051,7 0,0005

Rumput

Pembersihan/Penyapuan Areal $\quad 3479,7 \quad 0,0003$

Perkerasan

Penyiraman Rumput dan Tanaman $\quad 2303,7 \quad 0,0004$

Penutup Tanah dengan Sprinkler

Penyiraman Rumput dan Tanaman $\quad$ 1540,0 0,0006

Penutup Tanah dengan Selang

Plastik 3/4 Inch

Penyiraman Pohon dengan Selang $\quad 91,0 \quad 0,0110$

Plastik 3/4 Inch

Pemangkasan Rumput dengan $\quad 2475,2 \quad 0,0004$

Mesin Dorong Rover

Pemangkasan Rumput dengan $\quad$ 1293,6 $\quad 0,0008$

Mesin Gendong

Pemangkasan Tanaman Semak dan $\quad 84,0 \quad 0,0119$

Tanaman Penutup Tanah dengan

Gunting Pangkas

Pemangkasan Bentuk Tanaman $\quad 49,0 \quad 0,0204$

Perdu dan Pohon Kecil dengan

Gunting Pangkas

Penyiangan dan Penggemburan $\quad 49,0 \quad 0,0204$

Pohon dengan Cangkul dan Kored

Penyiangan dan Penggemburan $\quad 707,0 \quad 0,0014$

Tanaman Semak dengan Cangkul

dan Kored

Pemupukan Pupuk Organik pada $\quad 695,8 \quad 0,0014$

Tanaman Penutup Tanah

Pemupukan Pupuk Anorganik $\quad 1454,6 \quad 0,0007$

pada Tanaman Penutup Tanah

Pemupukan Pupuk Organik pada $\quad 56,0 \quad 0,0179$

Pohon

Pemupukan Pupuk Anorganik $\quad 70,0 \quad 0,0143$

pada Pohon

Penyemprotan Pestisida pada $\quad 1820,0 \quad 0,0005$

Tanaman Penutup Tanah dan

Semak dengan Sprayer Gendong

Penyemprotan Pestisida pada $\quad 721,0 \quad 0,0014$

Pohon Kecil dan Semak dengan

Sprayer Gendong

Penyulaman Tanaman Rumput $\quad 351,4 \quad 0,0028$

(Tandur)

Penyulaman Tanaman Rumput $\quad 591,5 \quad 0,0017$

(Lempengan)

Penyulaman Tanaman Penutup $\quad 953,4 \quad 0,0010$

Tanah dan Semak

\begin{tabular}{lrr}
\hline Penyulaman Tanaman Pohon & 35,0 & 0,0286 \\
\hline Penyikatan Perkerasan/Keramik & 899,5 & 0,0011
\end{tabular}

Pembuangan Sampah Taman $\quad 6,65 \quad 0,1504$

Sejauh sd. 200 meter

Pembuangan Sampah Taman $\quad 3,57 \quad 0,2801$

Sejauh 201 - 500 meter

Pengerukan Sedimen Saluran $\quad 67,2 \quad 0,0149$

Drainase

Pembersihan Lantai Bangunan $\quad$ 1575,0 0,0006

Taman

\begin{tabular}{lll}
\hline Pemasangan Steiger Pohon & 28,0 & 0,0357 \\
\hline Pemangkasan Pohon Sedang pada & 14,0 & 0,0714
\end{tabular}

Jalur

Pemangkasan Pohon Ringan pada $\quad 21,0 \quad 0,0476$




\begin{tabular}{|c|c|}
\hline Pekerjaan Pemeliharaan Taman & $\begin{array}{lc}\text { Kapasitas } & \text { Jumlah } \\
\text { Kerja Per } & \text { Tenaga/M } \\
\text { Hari }\left(\mathrm{m}^{2}\right) & \text { (HOri } \\
\text { (HOK) }\end{array}$ \\
\hline
\end{tabular}

Jalur

\begin{tabular}{lcc}
\hline Kapasitas Pemeliharaan Pagar Sling & 175,0 & 0,0057 \\
\hline Pengetrikan Rumput & 56,0 & 0,0179 \\
\hline Pekerjaan Pemangkasan & 21,0 & 0,0476
\end{tabular}

Ringan/Pohon Kecil (Diameter

Tajuk < 5m Tinggi 3-6 Meter)

Termasuk Angkutan Keluar Taman

\begin{tabular}{lcc}
\hline $\begin{array}{c}\text { Pekerjaan Pemangkasan Pohon } \\
\text { Besar dengan Tinggi }>\text { 6 m (PP } \\
\text { Termasuk Angkutan) }\end{array}$ & $\begin{array}{c}\text { Kapasitas } \\
\text { Kerja Per } \\
\text { Hari (m²) }\end{array}$ & $\begin{array}{c}\text { Jumlah } \\
\text { Tenaga/M2 } \\
\text { /Hari } \\
\text { (HOK) }\end{array}$ \\
\hline $\begin{array}{l}\text { Kapasitas Kerja Pemangkasan Berat } \\
\text { Pekerjaan Pemangkasan Sedang }(\varnothing<5\end{array}$ & 14,2 & 0,2381 \\
m) & 0,0714 \\
\hline Pekerjaan Pemangkasan Berat $(\varnothing<5 \mathrm{~m})$ & 7,0 & 0,1429 \\
\hline $\begin{array}{l}\text { Pekerjaan Pemangkasan Ringan }(\varnothing \\
\text { 5,1-10 m) }\end{array}$ & 13,6 & 0,0733 \\
\hline $\begin{array}{l}\text { Pekerjaan Pemangkasan Sedang }(\varnothing \\
5,1-10 \text { m) }\end{array}$ & 9,1 & 0,1099 \\
\hline $\begin{array}{l}\text { Pekerjaan Pemangkasan Berat }(\varnothing 5,1- \\
10 \text { m) }\end{array}$ & 5,2 & 0,1905 \\
\hline $\begin{array}{l}\text { Pekerjaan Pemangkasan Ringan }(\varnothing>10 \\
\text { m) }\end{array}$ & 7,7 & 0,1299 \\
\hline $\begin{array}{l}\text { Pekerjaan Pemangkasan Sedang }(\varnothing>10 \\
\text { m) }\end{array}$ & 6,8 & 0,1473 \\
\hline $\begin{array}{l}\text { Pekerjaan Pemangkasan Berat }(\varnothing>10 \\
\text { m) }\end{array}$ & 3,7 & 0,2695 \\
\hline Keterangan: $\varnothing$ adalah diameter tajuk & & \\
\hline
\end{tabular}

Keterangan: $\varnothing$ adalah diameter tajuk

Setiap pekerjaan pemeliharaan dapat diukur kapasitas kerjanya untuk memudahkan perhitungan efektivitas kerja pekerja pemeliharaan lanskap dalam menjalankan tugasnya. Kapasitas kerja adalah besarnya kemampuan tenaga kerja untuk melakukan suatu pekerjaan dalam waktu satu jam. Kapasitas kerja dipengaruhi oleh luas lahan, jenis pekerjaan, desain tapak, kelengkapan bahan dan alat serta pengawasan. Kapasitas kerja pemeliharaan taman dihitung berdasarkan luasan lahan per satuan Hari Orang Kerja (HOK).

Formula (5) Kapasitas Kerja $(K K)=$ Luas Lahan Waktu $x$ Jumlah Pekerja

Sedangkan Hari Orang Kerja (HOK) adalah kemampuan orang mengerjakan satu jenis pekerjaan dalam satu hari kerja dalam luasan tertentu. Kapasitas Kerja untuk setiap jenis pekerjaan pemeliharaan seyogyanya mengikuti standar tertentu sesuai situasi dan kondisi wilayah taman yang akan dipelihara. Dalam studi ini, penentuan standar kapasitas kerja untuk setiap jenis pekerjaan pemeliharaan dilakukan dengan mengumpulkan data dari responden tentang standar kapasitas kerja yang diberlakukan di beberapa instansi/perusahaan yang beroperasi di Indonesia dan sekitarnya. Responden yang digunakan dalam studi ini berjumlah 10 responden dari berbagai instansi dan perusahaan swasta yang bergerak di bidang pemeliharaan taman dengan beberapa data pembanding dari buku referensi terkait pemeliharaan taman dan pedoman dari Departemen Pekerjaan Umum.

\section{HASIL DAN PEMBAHASAN}

\section{Klasifikasi dan Kriteria Taman}

Masih berkaitan dengan perencanaan ruang terbuka yang terintegrasi sehingga menghasilkan produktivitas kerja yang optimum terkait pemeliharaan lanskap, maka perlu dibuat semacam klasifikasi taman untuk mengetahui kebutuhan PHL yang dalam merawat seluruh taman yang ada. Pekerja Harian Lepas (PHL) menyatakan bahwa PHL adalah pekerja borongan yang menerima upah harian. Upah yang diterima dapat diterima secara mingguan atau bulanan berdasarkan hasil kerjanya, termasuk juga pekerja harian yang dibayar berdasarkan volume hasil pekerjaan yang dilakukan secara borongan (Anggriani \& Saputra, 2019). Upaya pengklasifikasian taman diharapkan dapat menjadi rujukan dalam perhitungan standar kebutuhan PHL dengan kapasitas pekerjaan pemeliharaan tertentu dalam luasan taman tertentu sesuai klasifikasi. Pengklasifikasian ini dapat menjadi panduan dalam membangun taman-taman baru agar memenuhi standar dan memudahkan dalam pengelolaan taman. Taman kota juga merupakan salah satu tempat yang direkomendasikan untuk menghilangkan penat setelah beraktivitas seharian (Ayu, 2019; Mosyaftiani et. al., 2019). Gambar 1 juga menggambarkan desain minimal yang harus tersedia pada taman.

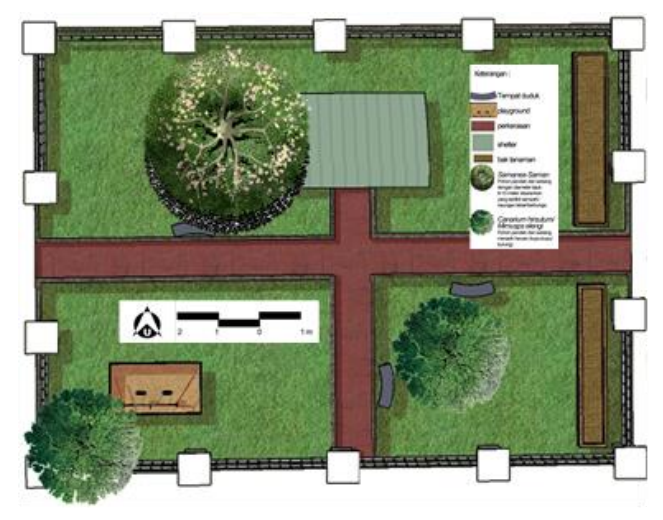

(a)

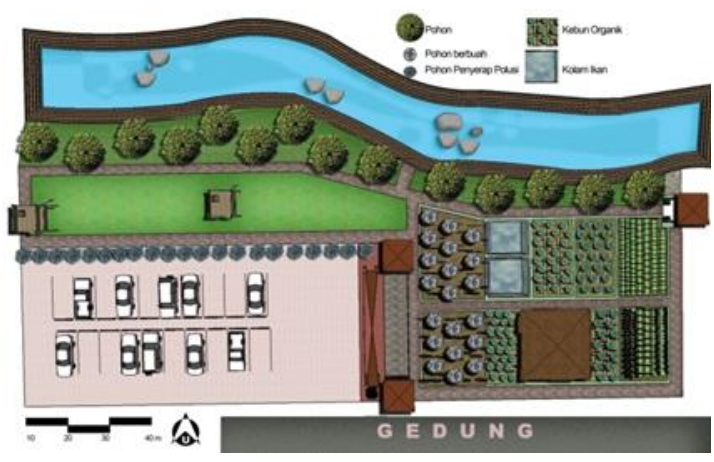

(b) 
1 Taman RT 1. Lokasi taman berada di radius kurang dari $300 \mathrm{~m}$ dari rumah penduduk yang dilayani. Luas minimal/unit adalah $250 \mathrm{~m}^{2}$.

2. Ditujukan untuk melayani penduduk dalam lingkup satu RT. Luas taman minimal $1 \mathrm{~m}^{2}$ per penduduk RT. Luas area yang ditanami (ruang hijau) seluas $70 \%-80 \%$ dari luas taman. Terdapat minimal 3 (tiga) pohon pelindung dari jenis pohon kecul atau sedang Ada fasilitas CPG, perkerasan, gazebo.

2 Taman RW 1. Ditujukan untuk melayani penduduk satu RW, khususnya kegiatan remaja, olahraga masyarakat, dll. Luas taman ini minimal $0,5 \mathrm{~m}^{2}$ per penduduk RW. Luas minimal taman adalah $1.250 \mathrm{~m}^{2}$. Lokasi taman berada pada radius kurang dari $1000 \mathrm{~m}$ dari rumah-rumah penduduk yang dilayaninya.

2. Luas area hijau adalah $70 \%-80 \%$ dari luas taman, sisanya pelataran atau perkerasan. Terdapat minimal 10 (sepuluh) pohon pelindung dari jenis pohon kecil atau sedang. Ada fasilitas CPG dan pedestrian, gazebo. Termasuk di dalamnya adalah taman RT.

3 Taman 1. Ditujukan untuk melayani penduduk satu kelurahan. Luas taman minimal $0,30 \mathrm{~m}^{2}$ per penduduk Kelurahan kelurahan. Luas minimal taman $9000 \mathrm{~m}^{2}$. Lokasi taman berada pada wilayah kelurahan yang bersangkutan.

2. Luas area hijau minimal $80 \%-90 \%$ dari luas taman, sisanya pelataran atau perkerasan. Terdapat minimal dua puluh lima (25) pohon pelindung dari jenis kecila tau sedang untuk jenis taman aktif, dan 50 pohon pelindung jenis kecil atau sedang untuk jenis taman pasif. Ada fasilitas CPG, lapangan olahraga, pedestrian, gazebo, plaza. Termasuk di dalamnya adalah taman RW.

4 Taman 1. Ditujukan untuk melayani penduduk satu kecamatan. Luas taman minimal 0,2 $\mathrm{m}^{2}$ per penduduk Kecamatan kecamatan. Luas taman minimal $24.000 \mathrm{~m}^{2}$. Lokasi taman berada pada wilayah kecamatan yang bersangkutan.

2. Luas area hijau minimal seluas $80 \%-90 \%$ dari luas taman, sisanya berupa pelataran dan perkerasan. Terdapat minimal 50 pohon pelindung dari jenis kecil atau sedang untuk taman aktif dan minimal 100 pohon tahunan dari jenis pohon kecil atau sedang untuk jenis taman pasif. Ada fasilitas CPG, lapangan olahraga, pedestrian, gazebo, plaza. Termasuk di dalamnya adalah taman kelurahan.

5 Taman 1. Ditujukan untuk melayani penduduk satu kota atau bagian wilayah kota. Melayani minimal Kota $\quad 480.000$ penduduk dengan standar minimal $0,3 \mathrm{~m}^{2}$ per penduduk kota. Luas taman minimal 144.000 $\mathrm{m}^{2}$. Dapat berbentuk RTH (lapangan hijau) yang dilengkapii fasilitas rekreasi danoilah raga, dan kompleks olah raga dengan minimal RTH $80 \%-90 \%$. Semua fasilitas terbuka untuk umum.

2. Jenis vegetasi adalah pohon tahunan, perdu, semak, semua ditanaman secara berkelompok, menyebar berfungsi sebagai pohon pencipta iklim mikro atau sebagai pembatas antar kegiatan. Terdapat jalur hijau, merupakan RTH, koridor antar bangunan, lapangan olahraga, dalam ukuran cukup besar. Termasuk di dalamnya adalah taman kecamatan.

Hutan 1. Bila Berbentuk bergerombol atau menumpuk, komunitas vegetasinya terkonsentrasi pada stru areal Kota dengan jumlah vegetasi minimal 100 pohon dengan jarak tanam rapat tidak beraturan. Bila bentuknya menyebar dengan tidak berpola khusus, luas minimalnya $2500 \mathrm{~m}^{2}$. Komunitas vegetasi tumbuh menyebar terpencar-pencarbdalam bentuk rumpun atau gerombol kecil.

2. Luas area hijaunya $90 \%-100 \%$ dari luas hutan kota. Bila berbentuk jalur, ia akan mengikuti bentukan sungai, jalan, pantai, saluran, dll.

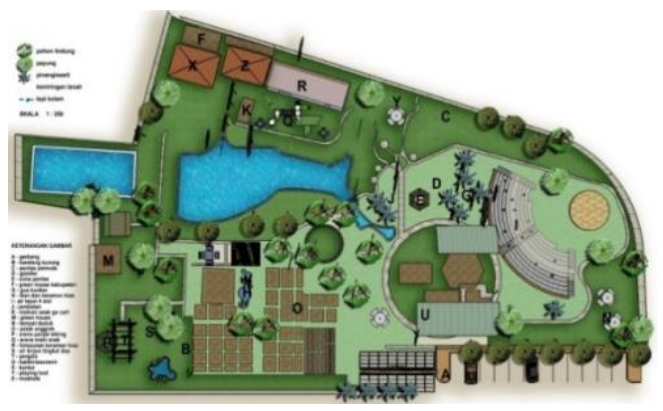

(c)

Gambar 1. (a) Contoh Desain Taman RT, (b) Contoh Taman RW, dan (c) Contoh Taman Kelurahan

Merujuk pada Permen PU Nomor 05/PRT/M/2008, disebutkan bahwa penyediaan RTH di perkotaan dapat dilakukan berdasarkan luas wilayah, berdasarkan jumlah penduduk, dan berdasarkan kebutuhan fungsi tertentu (Direktorat Jendral Penataan Ruang. Department Pekerjaan Umum, 2008). Taman-taman yang tersebar ini belum terklasifikasi dengan baik sehingga seringkali ketika akan dilakukan perhitungan kebutuhan PHL di bidang pemeliharaan taman, tidak dapat menggunakan satu acuan luasan taman sesuai klasifikasi. Ruang teduhan merupakan elemen yang sangat mempengaruhi aktivitas pengunjung yang datang ke taman Liwan Lake Park dikarenakan ruang tersebut banyak aktivitas yang dilakukan pada zoning tersebut (Fang et al., 2014). Dalam peraturan menteri disebutkan bahwa ruang terbuka hijau adalah area memanjang atau jalur atau mengelompok yang penggunaannya lebih bersifat terbuka, tempat tumbuh tanaman, baik yang tumbuh secara alamiah 
maupun yang sengaja ditanaman. Tabel klasifikasi dan kriteria taman dapat dilihat pada Tabel 2.

Klasifikasi taman perkotaan bertujuan untuk memudahkan dalam perhitungan kebutuhan PHL, dapat dilihat bahwa Taman RT sesuai data olahan maka harus memiliki luasan minimal $250 \mathrm{~m}^{2}$ dengan jumlah pohon minimal 3 pohon sesuai pada Gambar 1a. Klasifikasi taman perkotaan sesuai arahan Permen PU Nomor 05/PRT/M/2008 masih belum dapat diakomodasi di Kabupaten Jember karena taman kota yang saat ini eksisting adalah taman kota kecamatan dengan luas taman masih sangat minimal yaitu di antara 200-500 m², padahal seharusnya luas taman kecamatan adalah 24.000 $\mathrm{m}^{2}$ dengan luas area hijau minimal seluas $80 \%-90 \%$ dari luas taman, sisanya berupa pelataran dan perkerasan.

\section{Hasil Analisis Kapasitas Kerja pekerjaan Pemeliharaan}

Pemeliharaan dan perawatan yang rutin terhadap sebuah area lansekap akan sangat berpengaruh terhadap tampilan taman itu sendiri, berpengaruh terhadap nilainya sebagai sebuah kenyamanan (amenity) dan bahkan untuk jangka panjang, akan sangat berpengaruh terhadap komunitas tanaman dan alam secara keseluruhan (Afandi et al., 2012).

Memadupadankan antara bidang pemeliharaan dengan kebutuhan dari sebuah tapak atau taman itu sendiri merupakan bagian penting dari seni dan ilmu pengelolaan taman dan bahkan bisa memberikan formula yang pasti atau spesifikasi yang standar yang dapat diaplikasikan di beberapa tipe taman atau lanskap tertentu.

Pemeliharaan merupakan suatu usaha untuk menjaga dan merawat areal lanskap dengan segala fasilitas yang ada di dalamnya agar kondisi tetap baik atau sedapat mungkin mempertahankan pada keadaan yang sesuai dengan tujuan dan fungsi awal (Ruba et al., 2015). Selain itu, pemeliharaan juga bertujuan agar suatu areal lanskap memiliki suatu keindahan secara estetika serta nyaman dan aman. Tipe organisasi pemeliharaan ada tiga yaitu:

1. Sistem pemeliharaan unit (unit maintenance), yaitu pemeliharaan yang didasarkan pada unit-unit taman yang ada sehingga setiap unit taman mempunyai tim pemeliharaan sendiri;

2. Sistem tim pemeliharaan khusus (specialized maintenance crew) yaitu pemeliharaan didasarkan pada keahlian tertentu dari pegawainya, seperti pegawai khusus potong rumput atau pekerja khusus lainnya, berdasarkan jadwal pindah dari unit satu ke unit lainnya; dan

3. Sistem pemeliharaan secara kontrak (maintenance by contract) yaitu pemeliharaan diserahkan pada kontraktor sehingga seluruh pekerjaan pemeliharaan dikerjakan oleh kontraktor.

Tujuan kegiatan pemeliharaan adalah menjaga tapak beserta fasilitasnya supaya tetap dalam keadaan awal atau desain semula. Pemeliharaan alat dilakukan dalam upaya pencegahan, meliputi pembersihan dan pergantian oli mesin dan sebagainnya, tujuannya untuk memperpanjang umur alat yang digunakan. Bila terjadi kerusakan yang tidak dapat dihadapi, supervisor gardener melapor kepada housekeeping untuk dibuatkan surat work order yang ditujukan pada engineering untuk diperbaiki (Istacahyani et al., 2018). Untuk mencapai hasil yang diinginkan, perlu diperhatikan beberapa hal sebagai berikut:

1. Menetapkan prinsip-prinsip operasional;

2. Memelihara fasilitas dengan standar yang telah ditentukan; dan

3. Melakukan pengawasan dan evaluasi terhadap pelaksanaan kegiatan.

Pemeliharaan ideal adalah kegiatan pemeliharaan elemen-elemen lanskap baik soft material maupun hard material sehingga sesuai dengan tujuan dan fungsi semula. Dalam kegiatan pemeliharaan ini diharapkan taman, jalur hijau, kota, bahkan makam dapat memberikan keindahan dan kenyaman bagi pengguna dan penduduk kota dengan tetap mempertahankan desain awal yang telah dibentuk khusus. Sistem pemeliharaan yang ideal diterapkan yaitu sistem pemeliharaan unit dan karyawan pemeliharaan (Istacahyani et al., 2018). Untuk mempertahankan agar tujuan dan fungsi semula dalam pemeliharaan ideal tetap terjaga, diperlukan usaha yang menunjang pemeliharaan fisik, yaitu

1. Pembuatan jadwal pemeliharaan fisik untuk soft material dan hard material; dan

2. Pengganan tanaman lokal untuk memudahkan penggantian/penyulaman

Pemeliharaan tidak harus selalu menghabiskan dana yang besar dan dapat dikurangi jika didukung oleh upaya-upaya sebagai berikut

1. Perencanaan dan perancangan taman dengan pola yang sederhana sehingga memudahkan untuk melakukan pemeliharaan;

2. Pemilihan elemen tanaman yang baik; dan

3. Perancangan dengan pendekatan terhadap alam.

Pemeliharaan rutin untuk soft material antara lain penyiraman, pendangiran, penyiangan, pemangkasan, pemupukan, pengendalian/pencegahan dan pemberantasan hama penyakit tanaman dan penggantian tanaman yang rusak/mati. Sedangkan pemeliharaan rutin untuk hard material seperti perbaikan saluransaluran drainase, perbaikan atau pembersihan bangku taman, CPG, penyapuan atau pembersihan perkerasan, pembersihan kolam, dan segala jenis pemeliharaan untuk merawat elemen keras taman dari lumut atau karat dan lainnya. Keberadaan taman kota dengan kualitas yang optimal sangat penting bagi sebuah kota selain berfungsi sebagai fungsi ekologi juga berfungsi sebagai ruang publik yaitu untuk interaksi bagi masyarakat perkotaan (Pratomo et al., 2019).

Setelah dianalisis, diperoleh hasil akhir terkait data kapasitas kerja untuk masing-masing pekerjaan pemeliharaan yang meliputi pekerjaan penyapuan rumput, pedestrian dan rubberfloor, pembersihan sampah di kolam atau danau, penyiraman rumput, semak, tanaman hias dan pohon kecil/perdu, pemangkasan rumput, pemangkasan semak/penutup tanah/perdu/ pohon kecil, pendangiran dan penyiangan gulma; penyulaman tanaman semak/hias; penyulaman pohon; penyemprotan pestisida hingga pekerjaan pemangkasan pohon besar dengan tinggi $>6$ meter. Hasil analisis dapat dilihat pada tabel 3 . 
Tabel 3. Kapasitas kerja Pekerjaan Pemeliharaan

\begin{tabular}{|c|c|c|}
\hline Pekerjaan Pemeliharaan Taman & Satuan & $\begin{array}{l}\text { Kapasitas } \\
\text { Kerja/ } \\
\text { Jam }\end{array}$ \\
\hline Pemeliharaan Rubberfloor & $\mathrm{m}^{2} / \mathrm{jam}$ & 321,00 \\
\hline $\begin{array}{l}\text { Pencucian Pedestrian (Paving Blok, } \\
\text { Concrete, Keramik Tekstur Difabel) }\end{array}$ & $\mathrm{m}^{2} / \mathrm{jam}$ & 321,00 \\
\hline $\begin{array}{l}\text { Pembersihan Sampah di } \\
\text { Kolam/Danau }\end{array}$ & $\mathrm{m}^{3} / \mathrm{jam}$ & 85,00 \\
\hline $\begin{array}{l}\text { Pengerukan Sedimen Kolam Alami } \\
\text { (Manual) }\end{array}$ & $\mathrm{m}^{3} / \mathrm{jam}$ & 9,60 \\
\hline $\begin{array}{l}\text { Pembersihan/Penyapuan Areal } \\
\text { Rumput }\end{array}$ & $\mathrm{m}^{2} / \mathrm{jam}$ & 293,09 \\
\hline $\begin{array}{l}\text { Pembersihan/Penyapuan Areal } \\
\text { Perkerasan }\end{array}$ & $\mathrm{m}^{2} / \mathrm{jam}$ & 497,09 \\
\hline $\begin{array}{l}\text { Penyiraman Rumput dan Tanaman } \\
\text { Penutup Tanah dengan Sprinkler }\end{array}$ & $\mathrm{m}^{2} / \mathrm{jam}$ & 329,09 \\
\hline $\begin{array}{l}\text { Penyiraman Rumput dan Tanaman } \\
\text { Penutup Tanah dengan Selang Plastik } \\
3 / 4 \text { inch }\end{array}$ & $\mathrm{m}^{2} / \mathrm{jam}$ & 220,00 \\
\hline $\begin{array}{l}\text { Penyiraman Pohon dengan Selang } \\
\text { Plastik } 3 / 4 \text { inch }\end{array}$ & $\mathrm{btg} / \mathrm{jam}$ & 12,55 \\
\hline $\begin{array}{l}\text { Pemangkasan Rumput dengan Mesin } \\
\text { Dorong Rover }\end{array}$ & $\mathrm{m}^{2} / \mathrm{jam}$ & 353,64 \\
\hline $\begin{array}{l}\text { Pemangkasan Rumput dengan Mesin } \\
\text { Gendong }\end{array}$ & $\mathrm{m}^{2} / \mathrm{jam}$ & 184,82 \\
\hline $\begin{array}{l}\text { Pemangkasan Tanaman Semak dan } \\
\text { Tanaman Penutup Tanah dengan } \\
\text { Gunting Pangkas }\end{array}$ & $\mathrm{m}^{2} / \mathrm{jam}$ & 11,64 \\
\hline $\begin{array}{l}\text { Pemangkasan Bentuk Tanaman Perdu } \\
\text { dan Pohon Kecil dengan Gunting } \\
\text { Pangkas }\end{array}$ & $\mathrm{btg} / \mathrm{jam}$ & 6,45 \\
\hline $\begin{array}{l}\text { Penyiangan dan Penggemburan } \\
\text { Pohon dengan Cangkul dan Kored }\end{array}$ & $\mathrm{btg} / \mathrm{jam}$ & 6,18 \\
\hline $\begin{array}{l}\text { Penyiangan dan Penggemburan } \\
\text { Tanaman Semak dengan Cangkul dan } \\
\text { Kored }\end{array}$ & $\mathrm{m}^{2} / \mathrm{jam}$ & 100,43 \\
\hline $\begin{array}{l}\text { Pemupukan Pupuk Organik pada } \\
\text { Tanaman Penutup Tanah }\end{array}$ & $\mathrm{m}^{2} / \mathrm{jam}$ & 99,40 \\
\hline $\begin{array}{l}\text { Pemupukan Pupuk Anorganik pada } \\
\text { Tanaman Penutup Tanah }\end{array}$ & $\mathrm{m}^{2} / \mathrm{jam}$ & 207,79 \\
\hline $\begin{array}{l}\text { Pemupukan Pupuk Organik pada } \\
\text { Pohon }\end{array}$ & $\mathrm{btg} / \mathrm{jam}$ & 7,09 \\
\hline $\begin{array}{l}\text { Pemupukan Pupuk Anorganik pada } \\
\text { Pohon }\end{array}$ & $\mathrm{btg} / \mathrm{jam}$ & 9,82 \\
\hline $\begin{array}{l}\text { Penyemprotan Pestisida pada } \\
\text { Tanaman Penutup Tanah dan Semak } \\
\text { dengan Sprayer Gendong }\end{array}$ & $\mathrm{m}^{2} / \mathrm{jam}$ & 260,00 \\
\hline $\begin{array}{l}\text { Penyemprotan Pestisida pada Pohon } \\
\text { Kecil dan Semak dengan Sprayer } \\
\text { Gendong }\end{array}$ & $\mathrm{btg} / \mathrm{jam}$ & 102,60 \\
\hline $\begin{array}{l}\text { Penyulaman Tanaman Rumput } \\
\text { (Tandur) }\end{array}$ & $\mathrm{m}^{2} / \mathrm{jam}$ & 50,18 \\
\hline $\begin{array}{l}\text { Penyulaman Tanaman Rumput } \\
\text { (Lempengan) }\end{array}$ & $\mathrm{m}^{2} / \mathrm{jam}$ & 84,55 \\
\hline $\begin{array}{l}\text { Penyulaman Tanaman Penutup Tanah } \\
\text { dan Semak }\end{array}$ & $\mathrm{m}^{2} / \mathrm{jam}$ & 136,23 \\
\hline Penyulaman Tanaman Pohon & $\mathrm{btg} / \mathrm{jam}$ & 5,45 \\
\hline Penyikatan Perkerasan/Keramik & $\mathrm{m}^{2} / \mathrm{jam}$ & 128,55 \\
\hline $\begin{array}{l}\text { Pembuangan Sampah Taman Sejauh } \\
\text { sd. } 200 \text { meter }\end{array}$ & $\begin{array}{c}\text { karung/ } \\
\text { jam }\end{array}$ & 0,90 \\
\hline $\begin{array}{l}\text { Pembuangan Sampah Taman Sejauh } \\
201 \text { - } 500 \mathrm{~m}\end{array}$ & $\begin{array}{c}\text { karung/ } \\
\text { jam }\end{array}$ & 0,54 \\
\hline $\begin{array}{l}\text { Pengerukan Sedimen Saluran } \\
\text { Drainase }\end{array}$ & $\mathrm{m}^{3} / \mathrm{jam}$ & 9,60 \\
\hline Pembersihan Lantai Bangunan Taman & $\mathrm{m}^{2} / \mathrm{jam}$ & 225,00 \\
\hline Pemasangan Steiger Pohon & $\mathrm{btg} / \mathrm{jam}$ & 3,20 \\
\hline
\end{tabular}

\begin{tabular}{|c|c|c|}
\hline Pekerjaan Pemeliharaan Taman & Satuan & $\begin{array}{c}\text { Kapasitas } \\
\text { Kerja/ } \\
\text { Jam }\end{array}$ \\
\hline Pemangkasan Pohon Sedang & btg/jam & 1,35 \\
\hline Pemangkasan Pohon Ringan & $\mathrm{btg} / \mathrm{jam}$ & 2,00 \\
\hline Kapasitas Pemeliharaan Pagar Sling & $\mathrm{m} / \mathrm{jam}$ & 25,00 \\
\hline Pengetrikan Rumput & $\mathrm{m}^{2} / \mathrm{jam}$ & 8,25 \\
\hline $\begin{array}{l}\text { Pekerjaan Pemangkasan Ringan/ Pohon } \\
\text { Kecil (Diam Tajuk < } 5 \text { m Tinggi 3-6 m) } \\
\text { Termasuk Angkutan Keluar Taman }\end{array}$ & $\mathrm{btg} / \mathrm{jam}$ & 3,00 \\
\hline $\begin{array}{c}\text { Pekerjaan Pemangkasan Pohon Besar } \\
\text { dengan Tinggi > } 6 \mathrm{M} \text { (PP Termasuk } \\
\text { Angkutan) } \\
\end{array}$ & Satuan & $\begin{array}{l}\text { Kapasi tas } \\
\text { Kerja/ Jam }\end{array}$ \\
\hline Kapasitas Kerja Pemangkasan Berat & btg/jam & 0,6 \\
\hline Pekerjaan Pemangkasan Sedang $(\varnothing<5 \mathrm{~m})$ & btg/jam & 2,00 \\
\hline Pekerjaan Pemangkasan Berat $(\varnothing<5 \mathrm{~m})$ & $\mathrm{btg} / \mathrm{jam}$ & 1,00 \\
\hline $\begin{array}{l}\text { Pekerjaan Pemangkasan Ringan (Ø 5,1 s.d } \\
10 \mathrm{~m})\end{array}$ & $\mathrm{btg} / \mathrm{jam}$ & 1,95 \\
\hline $\begin{array}{l}\text { Pekerjaan Pemangkasan Sedang (Ø5,1 - } 10 \\
\text { m) }\end{array}$ & btg/jam & 1,30 \\
\hline $\begin{array}{l}\text { Pekerjaan Pemangkasan Berat (Ø 5,1 - } 10 \\
\mathrm{~m})\end{array}$ & $\mathrm{btg} / \mathrm{jam}$ & 0,75 \\
\hline Pekerjaan Pemangkasan Ringan $(\varnothing>10 \mathrm{~m})$ & btg/jam & 1,10 \\
\hline $\begin{array}{l}\text { Pekerjaan Pemangkasan Sedang }(\varnothing>10 \\
\mathrm{m})\end{array}$ & $\mathrm{btg} / \mathrm{jam}$ & 0,97 \\
\hline Pekerjaan Pemangkasan Berat $(\varnothing>10 \mathrm{~m})$ & btg/jam & 0,53 \\
\hline
\end{tabular}

Pekerjaan PHL yang pada Tabel 3 memiliki satuan yang beragam hal ini tergantung dari jenis pekerjaan, tingkat kesulitan pekerjaan, kemampuan/skill PHL, serta pengalaman. Pada pekerjaan yang memerlukan alat bantu yang berat seperti pada bagian pemangkasan, mdapat terlihat bahwa kapasitas kerja yang dapat dilakukan PHL dalam satuan jam berkisar antara 0,6 - 2 batang pohon/jam tergantung dari diameter pohon yang akan dipangkas. Pekerjaan penyapuan merupakan pekerjaan yang dapat dikategorikan ringan, terlihat dari data yang menunjukkan bahwa seorang PHL mampu melakukan kegiatan penyapuan seluas $497,09 \mathrm{~m}^{2} / \mathrm{jam}$.

\section{Frekuensi Kerja dalam Pekerjaan Pemeliharaan}

Pekerjaan pemeliharaan taman tidak selalu rutin dilakukan sepanjang tahun. Ada beberapa pekerjaan yang memang harus dilakukan sepanjang tahun dan ada beberapa pekerjaan yang hanya dilakukan beberapa kali dalam setahun. Beberapa kegiatan pemeliharaan, frekuensi pekerjaannya sangat terkait dengan bulan basah dan bulan kering karena jumlah curah hujan merupakan faktor yang sangat berpengaruh terhadap perkembangan pertumbuhan tanaman di lingkungan beriklim tropis. Sekitar setengah dari area taman adalah ruang hijau (termasuk area berumput dan area taman dengan tanaman) dan lebih dari sepertiga adalah ruang tanam (termasuk hamparan tanaman dan ruang taman umum) dan Perbedaan signifikan secara statistik dalam ukuran taman tidak ditemukan di antara empat kategori kepemilikan (Petrovic et al., 2019). Penggunaan waktu kerja berpengaruh negatif dan tidak signifikan terhadap variabel efektivitas kerja (Prihatin et al., 2019).

Kegiatan pemeliharaan yang dimaksud antara lain penyiraman dan pemangkasan. Penentuan jumlah bulan basah dan bulan kering ditentukan berdasarkan informasi dari Badan Meteorologi dan Geofisika tentang Prakiraan Musim Hujan. Penentuan jumlah bulan basah 
dan bulan kering menurut BMKG memang bervariasi, namun rata-rata dapat dikatakan bulan basah adalah 6 bulan (Oktober-Maret) dan bulan kering adalah 6 bulan (April-September) dapat dilihat pada Tabel 4.

Tabel 4. Frekuensi Pekerjaan Pemeliharaan Taman di Bulan Basah dan Bulan Kering

\begin{tabular}{|c|c|c|}
\hline \multirow{2}{*}{$\begin{array}{c}\text { Pekerjaan Pemeliharaan } \\
\text { Taman }\end{array}$} & $\begin{array}{c}\text { Frekuensi } \\
\text { Bulan Basah (6 } \\
\text { Bln/Thn) }\end{array}$ & $\begin{array}{c}\text { Frekuensi Bulan } \\
\text { Kering } \\
(6 \mathrm{~b} \ln / \mathrm{Thn})\end{array}$ \\
\hline & $\begin{array}{c}\text { Ha Satu } \\
\text { ri an }\end{array}$ & $\begin{array}{c}\text { Ha } \\
\text { ri atu } \\
\text { an } \\
\end{array}$ \\
\hline Pemeliharaan Rubberfloor & & \\
\hline $\begin{array}{l}\text { Pencucian Pedestrian } \\
\text { (Paving Blok, Concrete, } \\
\text { Keramik Tekstur Difabel) }\end{array}$ & $1 x / b \ln 6$ & $1 x / b \ln 6$ \\
\hline $\begin{array}{l}\text { Pembersihan Sampah Di } \\
\text { Kolam/Danau }\end{array}$ & 1x/hr 180 hr & 1x/hr 180 \\
\hline $\begin{array}{l}\text { Pengerukan Sedimen } \\
\text { Kolam Alami (Manual) }\end{array}$ & $1 x / b \ln 6$ & $1 x / \operatorname{bln} 6$ \\
\hline
\end{tabular}

Pembersihan/Penyapuan

Areal Rumput

Pembersihan/Penyapuan 1x/hr 180 hr 1x/hr 180 hr

Areal Perkerasan

Penyiraman Rumput dan

Tanaman Penutup Tanah

dengan Sprinkler

Penyiraman Rumput dan

Tanaman Penutup Tanah 1x/hr 180 hr 2x/hr 360 hr dengan Selang Plastik 3/4

Inch

Penyiraman Pohon dengan

Selang Plastik $3 / 4$ Inch

Pemangkasan Rumput

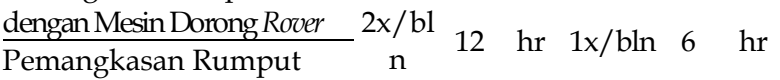

dengan Mesin Gendong

Pemangkasan Tanaman

Semak dan Tanaman

Penutup Tanah dengan

$\begin{array}{lcccccc}\text { Gunting Pangkas } & 2 \mathrm{x} / \mathrm{bl} & 6 & \mathrm{hr} & 1 \mathrm{x} / \mathrm{bln} & 6 & \mathrm{hr}\end{array}$

Pemangkasan Bentuk

Tanaman Perdu dan

Pohon Kecil dengan

Gunting Pangkas

Penyiangan dan

Penggemburan Pohon

dengan Cangkul Dan Kored

Penyiangan dan $1 \mathrm{x} / \mathrm{bl} \quad 6 \quad \mathrm{hr} \quad 1 \mathrm{x} / \mathrm{bln} \quad 6 \quad \mathrm{hr}$

Penggemburan Tanaman

Semak dengan Cangkul

dan Kored

Pemupukan Pupuk

Organik pada Tanaman

Penutup Tanah

Pemupukan Pupuk

$\begin{array}{lllll}1 \mathrm{x} / 3 \mathrm{bl} & 2 & \mathrm{hr} & 1 \mathrm{x} / 2 \mathrm{bln} \quad 3 & \mathrm{hr}\end{array}$

Anorganik pada Tanaman

Penutup Tanah

Pemupukan Pupuk

Organik pada Pohon $1 x / 3$ bln 2 hr $1 x / 2 b l n ~ 3 \quad h r$

Pemupukan Pupuk

Anorganik pada Pohon

Penyemprotan Pestisida

pada Tanaman Penutup

Tanah dan Semak dengan

Sprayer Gendong

2x/th 1 hr $2 x /$ thn 1 hr

Penyemprotan Pestisida

pada Pohon Kecil dan

Semak dengan Sprayer

\begin{tabular}{|c|c|c|}
\hline Pekerjaan & $\begin{array}{c}\text { Frekuensi } \\
\text { Bulan Basah (6 } \\
\text { Bln/Thn) }\end{array}$ & $\begin{array}{c}\text { Frekuensi Bulan } \\
\text { Kering } \\
\text { (6bln/Thn) }\end{array}$ \\
\hline & $\begin{array}{c}\text { Ha Satu } \\
\text { ri an }\end{array}$ & $\begin{array}{cc}\text { Ha } & \text { Satu } \\
\text { ri an }\end{array}$ \\
\hline
\end{tabular}

Gendong

Penyulaman Tanaman

Rumput (Tandur)

Penyulaman Tanaman

Rumput (Lempengan)

Penyulaman Tanaman insidentil $\mathrm{hr}$ insidentil $\mathrm{hr}$

Penutup Tanah Dan

Semak

Penyulaman Tanaman

Pohon

Penyikatan

Perkerasan/Keramik

Pembuangan Sampah

Taman Sejauh sd. 200

meter

$\begin{array}{lllllll}\text { Pembuangan Sampah } & 1 \mathrm{x} / \mathrm{bl} & 6 & \mathrm{hr} & 1 \mathrm{x} / \mathrm{bln} & 6 & \mathrm{hr}\end{array}$

Taman Sejauh 201 - $500 \mathrm{~m}$

Pengerukan Sedimen

Saluran Drainase

Pembersihan Lantai

Bangunan Taman

Pemasangan Steiger Pohon

Pemangkasan Pohon

Sedang insidentil $\mathrm{hr}$ insidentil $\mathrm{hr}$

Pemangkasan Pohon

Ringan

\begin{tabular}{llllllll}
\hline Kapasitas Pemeliharaan & $2 x /$ th & 1 & hr & $2 x /$ thn & 1 & hr
\end{tabular}

Pagar Sling $n$

\begin{tabular}{llllllll}
\hline Pengetrikan Rumput & $1 \mathrm{x} / \mathrm{bl}$ & 6 & $\mathrm{hr}$ & $1 \mathrm{x} / \mathrm{bln}$ & 6 & $\mathrm{hr}$
\end{tabular}

Pekerjaan Pemangkasan

Ringan/Pohon Kecil

(Diam Tajuk $<5 \mathrm{~m}$ Tinggi

3-6 Meter) Termasuk

Angkutan Keluar Taman

Kapasitas Kerja

Pemangkasan Berat

Pekerjaan Pemangkasan

Sedang $(\varnothing<5 \mathrm{~m})$ Temasuk

Angkutan

\begin{tabular}{|c|c|c|c|c|c|}
\hline \multirow{2}{*}{$\begin{array}{c}\text { Pekerjaan Pemangkasan } \\
\text { Pohon Besar dengan } \\
\text { Tinggi > } 6 \mathrm{M} \text { (PP } \\
\text { Termasuk Angkutan) }\end{array}$} & \multicolumn{2}{|c|}{$\begin{array}{c}\text { Frekuensi } \\
\text { Bulan Basah (6 } \\
\text { Bln/Thn) } \\
\end{array}$} & \multicolumn{3}{|c|}{$\begin{array}{c}\text { Frekuensi Bulan } \\
\text { Kering } \\
\text { (6bln/Thn) }\end{array}$} \\
\hline & $\mathbf{F}$ & $\begin{array}{cc}\text { Ha } & \text { Satu } \\
\text { ri an }\end{array}$ & $\mathbf{F}$ & $\begin{array}{c}\text { Ha } \\
\text { ri }\end{array}$ & $\begin{array}{c}\text { Satu } \\
\text { an }\end{array}$ \\
\hline
\end{tabular}

Pekerjaan Pemangkasan

Berat $(\varnothing<5 \mathrm{~m})$

Pekerjaan Pemangkasan

Ringan (Ø 5,1 - 10m)

Pekerjaan Pemangkasan

Sedang $(\varnothing 5,1-10 \mathrm{~m})$

Pekerjaan Pemangkasan insidentil hr insidentil hr

Berat $(\varnothing 5,1-10 \mathrm{~m})$

Pekerjaan Pemangkasan

Ringan $(\varnothing>10 \mathrm{~m})$

Pekerjaan Pemangkasan

Sedang $(\varnothing>10 \mathrm{~m})$

Pekerjaan Pemangkasan

Berat $(\varnothing>10 \mathrm{~m})$

Frekuensi pekerjaan pemeliharaan tergantung pada banyaknya bulan basah dan bulan kering. Ketika 
pemeliharaan dilakukan pada bulan kering intensitas pemeliharaan terlihat cukup tinggi pada beberapa pekerjaan yang berhubungan dengan penyiraman karena pada bulan tersebut penguapan terjadi cukup tinggi. Di lain sisi pada bulan basah kegiatan pemangkasan terlihat menjadi kegiatan dengan intensitas yang paling tinggi. yang biasa disebut Hutan Kota harus memiliki luas area hijau 90 - $100 \%$ dari luasan hutan kota.

Perhitungan kapasitas Pekerja Harian Lepas (PHL) dalam pemeliharaan taman pada satu jenis pekerjaan memiliki satuan yang dikonversi ke dalam jam. Besaran kapasitas pekerjaan tergantung dari tingkat kesulitan pekerjaan

Tabel 5. Kebutuhan Jumlah Pekerja Pada Standar Fasilitas Minimal Pada Tipe Taman RT, Taman RW, dan Taman Kelurahan

\begin{tabular}{|c|c|c|c|c|c|c|c|c|c|c|c|c|}
\hline Total Luas/Unit & \multicolumn{4}{|c|}{ Taman RT } & \multicolumn{4}{|c|}{ Taman RW } & \multicolumn{4}{|c|}{ Taman Kelurahan } \\
\hline $\begin{array}{ll}\text { a } & \text { Luas } \\
\end{array}$ & 250 & 250 & 1245 & 1245 & 1250 & 1250 & 8999 & 8999 & 9000 & 9000 & 23999 & 23999 \\
\hline $\mathrm{b} \quad \mathrm{CPG}$ & 0 & 0 & 0 & 0 & 0 & 0 & 0 & 0 & 0 & 0 & 0 & 0 \\
\hline c Perkerasan & 0 & 0 & 0 & 0 & 0 & 0 & 0 & 0 & 0 & 0 & 0 & 0 \\
\hline d Luas Rumput & 250 & 250 & 1245 & 1245 & 1250 & 1250 & 8999 & 8999 & 9000 & 9000 & 23999 & 23999 \\
\hline $\begin{array}{ll} & \text { Luas Tanaman } \\
\text { e } & \text { Hias }\end{array}$ & 0 & 0 & 0 & 0 & 0 & 0 & 0 & 0 & 0 & 0 & 0 & 0 \\
\hline $\begin{array}{ll}\mathrm{f} & \text { Luas Perdu } \\
\end{array}$ & 0 & 0 & 0 & 0 & 0 & 0 & 0 & 0 & 0 & 0 & 0 & 0 \\
\hline g Pohon & 3 & 9 & 3 & 9 & 10 & 24 & 10 & 24 & 25 & 49 & 25 & 49 \\
\hline $\begin{array}{l}\text { Jumlah Pekerja di } \\
\text { Bulan Kering }\end{array}$ & 0,57 & 0,72 & 2,47 & 2,62 & 2,66 & 3,01 & 17,46 & 17,81 & 17,84 & 18,44 & 46,49 & 47,10 \\
\hline $\begin{array}{l}\text { Jumlah Pekerja di } \\
\text { Bulan Basah }\end{array}$ & 0,37 & 0,45 & 1,64 & 1,73 & 1,75 & 1,96 & 11,72 & 11,92 & 11,94 & 12,29 & 31,22 & 31,57 \\
\hline $\begin{array}{l}\text { Rerata Jumlah Pekerja } \\
\text { Selama Satu Tahun }\end{array}$ & 0,47 & 0,59 & 2,06 & 2,18 & 2,21 & 2,49 & 14,59 & 14,87 & 14,89 & 15,37 & 38,86 & 39,34 \\
\hline Jumlah Pekerja/Bulan & 1 & 1 & 3 & 3 & 3 & 3 & 15 & 15 & 15 & 16 & 39 & 40 \\
\hline $\begin{array}{l}\text { Rerata Jumlah Pekerja } \\
\text { Tiap Taman }\end{array}$ & & & & & & & 9 & & & & & \\
\hline
\end{tabular}

Perhitungan kebutuhan PHL pada tiap tipe taman terntunya berbeda, pada tipe taman lingkup RT pastinya membutuhkan PHL yang lebih sedikit karena fasilitas yang tersedia pun juga tidak banyak. Dari hasil perhitungan yang dilakukan dengan fasilitas standar minimal yang dapat dilihat pada Tabel 5 menunjukkan bahwa kebutuhan PHL di Kabupaten Jember pada Taman RT adalah antara 1-3 orang, lain halnya pada Taman RW kebutuhan PHL antara 3-15 orang dan pada Taman Kelurahan adalah 15-40 orang. Kapasitas pekerja memperlihatkan pada bulan kering memiliki kenaikan yang signifikan dengan faktor pekerjaan yaitu pada penyiraman yang meningkat hingga dua kali kapasitas kerja.

\section{SIMPULAN}

Pemeliharaan dan perawatan yang rutin terhadap sebuah area lanskap akan sangat berpengaruh terhadap tampilan lanskap itu sendiri, dan juga berpengaruh terhadap nilainya sebagai sebuah kenyamanan (amenity) dan bahkan untuk jangka panjang, akan sangat berpengaruh terhadap komunitas tanaman dan alam secara keseluruhan. Hal ini benar adanya karena pemeliharaan merupakan upaya untuk mempertahankan keindahan dan fungsi sebuah lanskap atau taman.

Klasifikasi dan kriteria taman perkotaan sesuai dengan standar yaitu Peraturan Menteri Pekerjaan Umum membagi kriteria taman menjadi Taman RT dan Taman RW memiliki luasan minimal $250 \mathrm{~m}^{2}$ dan $1.250 \mathrm{~m}^{2}$ dengan persentasi $70-80 \%$ adalah luas area hijau. Taman Kelurahan, Taman Kecamatan, dan Taman Kota harus memiliki luasan area hijau minimal $80-90 \%$ dari luas taman. Bila Berbentuk bergerombol atau menumpuk atau serta keahlian dan kemampuan pekerja. Pada pekerjaan pemangkasan memiliki kapasitas pekerjaan paling kecil karena memerlukan keahlian lebih lanjut dalam bentuk pelatihan dan sertifikasi pemangkasan pohon.

Penentuan intensitas pekerjaan pemeliharaan dalam taman, selain harus mempertimbangkan berbagai faktor seperti jumlah luasan area dari komponen dalam taman (elemen keras maupun elemen lunak taman), kapasitas kerja dari masing-masing pekerjaan pemeliharaan, frekuensi pekerjaan pemeliharaan di bulan basah dan bulan kering, dan waktu kerja efektif dari tenaga kerja. Frekuensi pekerjaan pemeliharaan pada bulan kering dilakukan dengan intensitas lebih tinggi terutama pada pekerjaan penyiraman dengan kapasitas kerja meningkat sebanyak dua kali kapasitas kerja, namun ada pekerjaan yang memang dilakukan insidentil seperti pemangkasan, penyulaman, penyikatan perkerasan dan keramik karena pekerjaan ini dilakukan apabila ada pelaporan dari warga. Saran dari penelitian ini masalah performa dari para pekerja harus menjadi perhatian karena akan mempengaruhi efektivitas dan efisiensi manajemen pemeliharaan. Pekerjaan PHL yang pada merupakan pekerjaan per satuan jenis pekerjaan, namun faktanyanya di lapangan yang harus dikerjakan tidak hanya satu jenis pekerjaan. Sehingga perlu suatu rumusan atau formula untuk menghitung banyaknya pekerja yang dibutuhkan pada suatu taman.

\section{DAFTAR PUSTAKA}

Afandi, A., Neolaka, A., Saleh, R. 2012. Kesadaran Lingkungan Masyarakat dalam Pemeliharaan Taman Lingkungan di Jakarta Pusat. Menara: Jurnal Teknik Sipil, 7(1), 14. https://doi.org/10.21009/ jmenara.v7i1.7947 
Anggriani, I., Saputra, A. R. 2019. Analisis Perbedaan Produktivitas Kerja Karyawan Tetap, Kontrak dan Pekerja Harian Lepas (PHL) di PDAM Kota Bengkulu. EKOMBIS REVIEW: Jurnal Ilmiah Ekonomi dan Bisnis. https:// doi.org/10.37676/ekombis. v7i1.702

Ayu, A. P. 2019. Peran Ruang Terbuka Hijau dalam Citra Kota Studi Kasus: Taman Suropati, Jakarta. Jurnal Ilmiah Desain $\mathcal{E}$ Konstruksi, 18(1), 53-66. https://doi.org/10.35760/dk.2019.v18i1.1958

Direktorat Jendral Penataan Ruang. Departemen Pekerjaan Umum. 2008. Pedoman Penyediaan dan Pemanfaatan Ruang Terbuka Hijau di Kawasan Perkotaan. Pedoman Penyediaan dan Pemanfaatan Ruang Terbuka Hijau Di Kawasan Perkotaan.

Fang, X. S., Luo, J. P., Meng, Q. L., Liang, H. F. 2014. A Preliminary Study of Thermal Comfort Threshold Value in Subtropical Country Park-Take Guangzhou Tianlu Lake Country Park in Spring for Example. International Conference on Water Resource and Environmental Protection Wrep 2014.

Hantono, D. 2017. Pola Aktivitas Ruang Terbuka Publik Pada Kawasan Taman Fatahillah Jakarta. Jurnal Arsitektur KOMPOSISI, 11(6), 265. https:// doi.org/ 10.24002/jars.v11i6.1360

Istacahyani, I. A. M., Semarajaya, C. G. A., Pradnyawathi, N. L. M. 2018. Evaluasi Pemeliharaan Taman pada Kawasan Bali Tropic Resort and Spa Kabupaten Badung. Jurnal Arsitektur Lansekap, 168. https://doi.org/10.24843/JAL.2018. v04.i02.p06

Mosyaftiani, A., Kaswanto, R. L., Arifin, H. S. 2019. Ground Vegetation Diversity on Different Type of Riverbank Along Ciliwung River in Bogor City, West Java. HAYATI Journal of Biosciences 26(1):35.
Noor, A., Winandari, M. I. R., Ischak, M. 2018. Karakter Pengguna Ruang Publik di Taman Ayodya Jakarta Selatan. Jurnal Penelitian dan Karya Ilmiah Arsitektur Usakti, 16(02), 60. https://doi.org/10.25105/agora. v16i02.3229

Permata, N. D., Syartinilia, Munandar, A. 2019. Pemanfaatan Hutan Kota di Wilayah Jakarta Timur Sebagai Kawasan Rekreasi Masyarakat Kota. Jurnal Lanskap Indonesia, 10(2), 47-55. https://doi.org/ 10.29244/jli.2018.10.2.47-55

Petrovic, N., Simpson, T., Orlove, B., Dowd-Uribe, B. 2019. Environmental and Social Dimensions of Community Gardens in East Harlem. Landscape and Urban Planning, 183: 36-49. https:/ / doi.org/10.1016/ j.landurbplan.2018.10.009

Pratomo, A., Soedwiwahjono, S., Miladan, N. 2019. Kualitas Taman Kota sebagai Ruang Publik di Kota Surakarta Berdasarkan Persepsi dan Preferensi Pengguna. Desa-Kota, 1(1), 84. https://doi.org/ 10.20961/desa-kota.v1i1.12494.84-95

Prihatin, W. N., Fathoni, A., Wulan, H. S. 2019. Analysis Of Use of Work Time and Work Loads On The Effectiveness of Work with Work Satisfaction as an Intervening Variable In Pt Visionland Karangjati Semarang District. Journal of Management, 5 .

Ruba, V. C. F., Utami, N. W. F., Adnyana, G. M. 2015. Pemeliharaan Fisik Taman Nostalgia Kota Kupang Provinsi Nusa Tenggara Timur. Jurnal Arsitektur Lansekap. https://doi.org/10.24843/jal.2015.v01.i02. p02

Setyabudi, I., Agus, V. T. S. 2020. Redesain Taman Kota Trunojoyo Kota Malang Melalui Pendekatan Lanskap Kota. Jurnal Lanskap Indonesia, 12(2), 7988. https:// doi.org/10.29244/jli.v12i2.32690 